\title{
Research on the Fusion Development Trend of International Trade Theory and International Direct Investment Theory
}

\author{
Bo Liu \\ English School, China West Normal University, Sichuan, Nanchong, China, 637009
}

Keywords: Fusion Development Trend, International Trade Theory, International Direct Investment Theory

\begin{abstract}
Traditional theories of international trade and international direct investment are based on completely different analytical frameworks. However, with the development of economic globalization and people's deepening understanding of international trade and the phenomenon of international direct investment, people gradually find that international trade and international direct investment are actually different choices faced by the same enterprise. When they export or set up production bases in the host country, the factors that should be considered are largely similar. Therefore, some scholars try to fill the gap between international trade theory and FDI theory and establish an analytical framework that integrates international trade with international direct investment.
\end{abstract}

\section{Introduction}

International trade and international direct investment are two alternative ways for enterprises to operate internationally. International trade manifests itself as a transboundary movement of goods, whereas international direct investment manifests itself as a cross-border movement of capital-based factors of production. Although these two economic behaviors have different manifestations, they can greatly promote the economic growth of a country through an approximate mechanism. With the continuous development of economic globalization, the relationship between trade and investment is getting closer and closer. The factors considered by multinational enterprises in the strategic choice of international trade or FDI are largely similar to those developed by one country trade and investment policies also often contain one another. Therefore, it is apparently an outdated view of the influence of trade and investment in isolation. In particular, it is not conducive to the coordination and mutual support of the objectives of trade and investment policies. From the point of view of the practice of world economic development, the recent liberalization of foreign direct investment due to trade restrictions and the inefficiency of trade due to restrictions on foreign investment reflect the fact that countries are defending trade policy and investment policy formulation, lack of systematic and integrated awareness. This objectively requires that we must re-understand the relationship between trade and investment in theory, this article attempts to make a tentative study [1].

\section{The Divergence of the Early Theory}

There is a natural gap between the traditional theory of international trade and the theory of international direct investment. This is primarily because the traditional theory of international trade is based on an ideal neo-classical analytical framework. In this framework, the market is perfectly competitive. Many of the most important variables are omitted by their strict presuppositions. Therefore, trade is the most sensible choice of an enterprise or a country, and foreign direct investment is not considered.

Both the classical theories of Smith and Ricardo, and the Heckscher-Ohlin neoclassical theory, not only have their analytical logic and policy propositions come from the same strain, but also the basic premise of their theories is basically the same. The Heckscher-Ohlin model shows that the direct cause of international trade lies in the price differences among countries in producing the 
same kind of goods, while the price differences are caused by the differences in costs. The differences in costs result from the different prices of the factors of production in various countries. The price of the factors of production is determined by the abundance of factors of production. It is precisely because of the abundance of factors of production in different countries that determine the comparative advantage or price advantage that each country has in producing different products. Therefore, a country imports more heavily-used commodities manufactured by its abundant factors of production to use their scarce factors of production of goods manufactured.

It can be seen that in the neoclassical international trade model, the theory of international trade has not left any room for growth in the theory of international direct investment. Therefore, the early theory of international direct investment cannot be derived within the framework of international trade theory, but can only find another way to seek a totally different explanation. The theory of monopoly dominance was put forward by S.H. Hymer, the founder of FDI theory, in his doctoral thesis "International Business of Domestic Enterprises: A Study of Foreign Direct Investment" completed in 1960. The explanation of the behavior of multinational corporations by monopoly superiority theory is based on the premise of imperfect competition in the market. This premise is totally different from the analysis of neoclassical international trade theory because under the condition of complete competition, Equal power of all factors of production, a single enterprise does not have the power to affect the market, enterprises do not have the ability to invest abroad, and foreign investment will not give any added advantage to the enterprise, the theory of monopoly advantage of Heimer on the contrary, he believes that not only International markets, but also the domestic market is not complete, multinational investment is the product of incomplete markets. Market imperfections are manifested in the commodity markets as commodity-specific, trademarks, special market skills or price alliances; performance in the factor markets as special management skills, convenience in capital markets and technical aspects protected by the patent system Differences and so on. Market imperfections are also manifested in economies of scale and differences in tariffs, taxes, interest rates and exchange rates among different countries. The incompleteness of the market has led to the monopoly advantage of a few enterprises. It is these monopoly advantages that make it possible for some enterprises to cross borders and overcome the added cost of transnational operations and to fiercely compete with local enterprises in the host country [2]. The monopoly advantage that multinational corporations have is a condition for multinationals to ensure profitable cross-border production and also serves as a starting point for the theory of international direct investment. This analytical perspective is completely different from the general equilibrium analysis framework of international trade theory.

\section{The Cross of the Theoretical Development}

The earlier incorporation of foreign trade and international investment into an integrated analytical framework was R.vernon, the founder of the theory of product cycles. In May 1966, Vernon published an article entitled "International Investment and International Trade in the Product Cycle" in the Quarterly Journal of Economics. Vernon believes that monopoly superiority theory does not completely explain why transnational corporations need to establish an overseas subsidiary to occupy the market, rather than choose the form of export products or licenses to take advantage of their monopoly. There is a need to establish a dynamic theory that systematically explains the choice of firms between their exports and the production and licensing of their foreign affiliates. Vernon divided the product life cycle into three phases, the "new" phase of the product, the "mature" phase and the "standardization" phase. In his opinion, linking the different stages of the product cycle to the location choices made by firms can illustrate the firm's choice of connection between overseas production and exports. In the "new" phase of the product, the firm has a propensity to choose to produce domestically because the price elasticity of demand for the product at this stage is very low, the enterprise has a monopoly advantage, and the domestic production can continuously improve the product and keep the same between the customer and the supplier In the "mature" stage of the product, due to the maturing of production technology and the basic stereotyping of products, the export volume of products has sharply increased, which has led to the 
proliferation of production technology to foreign competitors, Imitations began to emerge, the marginal cost of production plus the transportation costs of export commodities gradually approached and exceeded the expected average cost of production in the import market, and competition turned to the cost of production. Therefore, enterprises in innovative countries needed to be close to the type of domestic demand of the state investment in factories to reduce production costs and maintain their market share; when the product into the "standardization" stage, the monopoly advantage of enterprises have disappeared, the basis of competition is only the price competition, the result is the product Production or assembly operations have gradually shifted to developing countries with low labor costs the inventor turned to importing the product from abroad. The description of the close relationship between trade, foreign direct investment and firm growth made possible by the product cycle theory makes it possible to incorporate international trade theory and FDI theory into a unified analytical framework. However, in the development of international trade theory, it is still strictly assumed that enterprises produce goods or services only in a certain area while excluding foreign direct investment from the framework of analysis. Even after Lyottiff's empirical study on the neoclassical trade after the theory is put on suspicion, there is still no fundamental change. However, the interpretation of Lyottiff's mystery has opened the way for the study of the theory of modern international trade. International trade theory began to relate more to the reality and constantly broke through the preconditions of the neoclassical trade theory, so that the emergence of international trade theory and international The Convergence of the Premise of Direct Investment Theory and the Crossing of Some Analytic Contents.

Progress in the new factor trade theory is limited because the economic environment it analyzes still assumes that domestic markets are completely competitive and that there is no free movement of factors of production between countries. What has made a big breakthrough in this regard is the theory of new technology trade. According to the theory of new technology and trade, the major differences among countries in the production technology are the important reasons for the international trade. Technological gaps make the difference in factors abundance less relevant, and the degree of factor abundance should not be the only basis for interpreting international trade. By critiquing the theory of factor inspection, the theory of new technology trade has taken a big step toward the real world. It actually expands Ricardo's comparative cost theory and thus jumps out of the framework of neoclassical trade theory [3].

\section{The Trend of Theoretical Integration}

The above-mentioned phenomenon of cross-cutting in theoretical development is not yet the conscious action of people. In theory, the study of the linkages between international trade and international investment has not been taken seriously. With the rapid development of transnational corporations in the world, the international integrated production and intra-company trade of transnational corporations have gradually become an important force for promoting the development of international economy and trade. People began to realize that trade and investment are actually different options for the same business to operate internationally. Therefore, a theory can be established to organically link the two in order to seek a coordinated interpretation.

This attempt is carried out in different ways. S. Hirsch sets up a decision-making model for enterprises on export trade and foreign investment from the perspective of cost. This model shows in a relatively concise way the choice of export under which conditions and under what conditions investment. Hirsch's 1976 article, "International Trade in Manufactures and International Investment," presented the following model: In the case of a country A, for example, an enterprise's exports or direct investments in country B depend on the following conditions:

If $\mathrm{P} .+\mathrm{M}(\mathrm{Pb}+\mathrm{K}$; and $\mathrm{P} .+\mathrm{M}(\mathrm{Pb}+\mathrm{C}$, then choose to export to country $\mathrm{B}$. $)$.

If $\mathrm{Pb}+\mathrm{e}<\mathrm{Pb}+\mathrm{K}$; and $\mathrm{pb}+\mathrm{e}<\mathrm{p}$. $+\mathrm{M}$, then direct investment in country $\mathrm{B}$.

$\mathrm{P}$. And $\mathrm{Pb}$ represent the cost of production in country A and country $\mathrm{B}, \mathrm{K}$ represents firm expertise and intangible assets, $\mathrm{M}$ represents the difference between the cost of export sales over the cost of sales in the country, and $\mathrm{c}$ the additional cost of managing and coordinating foreign operations. The basic meaning of the model is as follows: When the sum of domestic production 
cost and export sales cost is less than the sum of foreign production cost and additional coordination cost and less than the sum of foreign production cost and technology loss cost (similar to the license form), the enterprise will choose The mode of export trade participates in international business. When the sum of foreign production cost and additional coordination cost is less than the sum of domestic production cost and export sales cost, and less than the sum of foreign production cost and technology loss cost, the enterprise will choose the way of foreign investment International business [4].

The model has a strong comprehensive effect. The three key variables $\mathrm{M}, \mathrm{C}, \mathrm{K}$ in the model are in fact a major expansion of the $\mathrm{H}-0$ model. After adding $\mathrm{Pa}$ and $\mathrm{Pb}$, the model includes the location factors among countries, which can be a good explanation of various investment theories. Attempting to establish the theory of international direct investment as one of the cornerstones of international trade devaluates Kojima Koji, Hitotsubashi University, Japan. From the late 1970s to the mid-1980s, Kojima made a large number of treatises on international direct investment. He criticized early international investment theories for ignoring the analysis of macroeconomic factors, especially ignoring the role of the international division of labor. Kojima clearly believes that the principle of international division of labor and the principle of comparative cost are consistent. The international division of labor can explain both foreign trade as well as foreign direct investment. Therefore, the comprehensive theory of international trade and foreign investment can be based on comparative advantage (cost).

Into the 90's, the trend of integration of international direct investment theory and international trade theory further deepened, the theory of international trade more and more close to reality, many of the traditional assumptions were relaxed or abandoned, the theoretical analysis is no longer confined to industry or national level, and It seeks to integrate the theory of enterprise behavior, the theory of industrial organization with the differences in resources and industry at the state and national levels, and the theory of international division of labor. The theory of international direct investment is no longer confined to the analysis of the behavior of a single enterprise, but also studies the relationship between international direct investment and international trade from the combination of industry or the behavior of a country and a multinational corporation, so that both the basis of the analysis and its basic conclusions More and more consistent. Although so far there have been no theories of FDI and international trade that have a significant impact but are widely recognized by theorists, the process of theoretical development deserves full affirmation. Recalling the major differences in early theories, it should be said that the contribution of theoretical development is enormous [5].

\section{Conclusions}

Since the reform and opening up, international trade and FDI have become an important force driving Chinese economic growth. Based on the reality that international trade and international direct investment are increasingly converging, in particular, the integrated mode of production of multinational corporations has penetrated into the open economy Among them, whether we are developing foreign trade or actively utilizing foreign investment, we should pay attention to the coordination of these two policies so as to ensure that trade and investment can achieve a real interaction and a virtuous circle, and ultimately serve our country's economic growth and sustainable development.

\section{References}

[1] Yellow River. On the integration of international trade theory and international direct investment theory under comparative advantages [J] .International Trade and Economic Exploration, 2002 (02).123.

[2] ZHU Yujie, Zeng Daoxian, Nie Xiaogang.Study on the Advantage and Complementarity of International Direct Investment [J]. Journal of Tsinghua University (Philosophy and Social Sciences 
Edition), 2001 (05)55.

[3] Huang Xianhai, Lin Gujiao. The International Trade Effect of FDI: An Expansion Model and Empirical Analysis [J] .Zhejiang Social Sciences. 2001 (05).45-49.

[4] Yu Haifeng, Feng Zhongquan. Development and Evolution of International Direct Investment Theory after World War II [J] .International Trade and Economic Exploration, 2001 (02).80-82.

[5] Xie Bing. Foreign Direct Investment Trade Effects and Empirical Analysis [J].Economic Review. 2000 (04).33. 